\title{
Characterization of human gastric adenocarcinoma cell lines established from peritoneal ascites
}

\author{
BOŻENNA MYTAR ${ }^{1}$, MAŁGORZATA STEC ${ }^{1}$, RAFAŁ SZATANEK ${ }^{1}$, KAZIMIERZ WĘGLARCZYK $^{1}$, \\ KATARZYNA SZEWCZYK ${ }^{2}$, ANTONI SZCZEPANIK ${ }^{3}$, GRAŻYNA DRABIK ${ }^{4}$, JAREK BARAN ${ }^{1}$, \\ MACIEJ SIEDLAR $^{1}$ and MONIKA BAJ-KRZYWORZEKA ${ }^{1}$ \\ Departments of ${ }^{1}$ Clinical Immunology and ${ }^{2}$ Medical Genetics Institute of Pediatrics, \\ Jagiellonian University Medical College, 30-663 Krakow; ${ }^{3}$ First Department of General Gastrointestinal and \\ Oncology Surgery, Jagiellonian University Medical College, 30-001 Krakow; ${ }^{4}$ Department of Transplantation, \\ Institute of Pediatrics, Jagiellonian University Medical College, 30-663 Krakow, Poland
}

Received September 15, 2017; Accepted December 28, 2017

DOI: $10.3892 / 01.2018 .7995$

\begin{abstract}
The three cell lines, designated as gastric cancer (GC)1401, GC1415 and GC1436 were derived from peritoneal effusions from patients with gastric adenocarcinoma. Cell lines were established in tissue culture and in immunodeficient, non-obese diabetic/severe combined immunodeficiency (NOD/SCID) mice. All cell lines were cultured in Dulbecco's modified Eagle's medium supplemented with 5\% fetal bovine serum. These cell lines were grown as an adherent monolayer with doubling time ranging between $25 \mathrm{~h}$ (GC1436 cell line) and 30-34 h (GC1401 and GC1415, respectively). All cells showed morphological features of epithelial-like cells, forming sheets of polygonal cells. Chromosomal analysis showed that the modal numbers ranged from 52 (GC1401), 51-56 (GC1415) and 106 (GC1436). High heterogeneity, resulting from several structural and numerical chromosomal abnormalities were evident in all cell lines. The surface marker expression suggested a tumor origin of the cells, and indicated the intestinal phenotype of a GC $\left(\mathrm{CD} 10^{+}, \mathrm{MUC1}\right)$. All three cell lines were tumorigenic but not metastatic, in vivo, in NOD/SCID mice. The lack of metastatic potential was suggested by the lack of aldehyde dehydrogenase 1A1 activity. In conclusion, these newly established GC cell lines widen the feasibility of the functional studies on biology of GC as well as drug testing for potential therapeutic purposes.
\end{abstract}

\section{Introduction}

Gastric cancer (GC) is the fifth most common malignancy in the world and the third in cancer-related death (1). One of the reasons behind high mortality is that patients at the time

Correspondence to: Dr Monika Baj-Krzyworzeka, Department of Clinical Immunology, Jagiellonian University Medical College, Wielicka 265, 30-663 Krakow, Poland

E-mail: mibaj@cyf-kr.edu.pl

Key words: gastric adenocarcinoma, ALDH, Her-2/neu of diagnosis are usually at an advanced tumor stage, hence the need for new, more effective diagnostic and therapeutic approaches is urgent. Also, despite different therapies (surgery, chemotherapy, targeted therapy) the prognosis for patients is still poor (2). Among others, the reason for this poor prognosis may lie in the biological heterogeneity of cancer cells, comprising their morphology and, more importantly, their functionality (3). Established tumor cancer cell lines are a very useful tool for studying cancer cell biology, heterogeneity or sensitivity to different drugs and therapies. A comprehensive collection of well-described cell lines should reflect the diversity of GC and provide adequate models for its study. Up to date, just a few GC cell lines are available, most of them being established from Asian patients (4-6), where this type of cancer is most prevalent.

In the present study we characterize three, new cell lines established from ascitic fluids of Caucasian patients with GC. The karyotype (by conventional G-banding) of these cells, their phenotype [including tumor-associated antigens (TAA) such as c-Met, Her-2/neu, Tag72, EMA, Epithelial Antigen and EMMPRIN], mRNA expression profile (Her-2/neu, MAGE-1) and growth in immunodeficient mice are presented. In addition, the expression and activity of aldehyde dehydrogenase (ALDH) isoforms relevant to metastatic potential of cancer cells are documented (7-11).

In conclusion, the presented data widens the current knowledge on GC cells and provides a liable laboratory model for anticancer drug testing and tumor proliferation studies.

\section{Materials and methods}

Origin of cell lines. Tumor cell lines were established from carcinomatous ascites of three patients with advanced GC diagnosed at the First Department of General Gastrointestinal and Oncology Surgery of the Jagiellonian University Medical College (Krakow, Poland). Patients provided their informed, written consent in the present study. The study was approved by the Jagiellonian University Ethical Committee (KBET/491/B/2003). Ascites were harvested into sterile bottles with heparin, centrifuged at $110 \mathrm{x}$ g for $5 \mathrm{~min}$. Thereafter both 
the cells and the ascitic fluids were collected. The ascitic fluids were filtered and kept at $-80^{\circ} \mathrm{C}$ until use. The cell pellet was resuspended $\left(1 \times 10^{6} / \mathrm{ml}\right)$ in DMEM medium with high glucose (Sigma-Aldrich; Merck KGaA, Darmstadt, Germany) supplemented with $5 \%$ fetal bovine serum (FBS; Biowest, Nuaille, France), $40 \%$ of autologous ascitic fluid and $50 \mu \mathrm{g} / \mathrm{ml}$ gentamycin (Sigma-Aldrich; Merck KGaA). When the cells started to grow rapidly, the ascitic fluid, after a period of gradual decrease, was completely withdrawn from the culture. The cells were incubated at $37^{\circ} \mathrm{C}$ in $5 \% \mathrm{CO}_{2}$ atmosphere and regularly tested for Mycoplasma sp. contamination by PCR-ELISA kit (Roche, Mannheim, Germany) and for endotoxin contamination by the Limulus test (Charles River Laboratories, Wilmington, MA, USA) according to manufacturer's instruction.

For analysis of cellular morphology, an inverted phase-contrast microscope (Olympus, Tokyo, Japan) was used.

Doubling time (growth curves). Cells $\left(1 \times 10^{5} / \mathrm{ml}\right)$ in medium supplemented with 5\% FBS and $50 \mu \mathrm{g} / \mathrm{ml}$ gentamycin (further referred as complete medium) were seeded in duplicates into 24-well plates (BD Falcon, Franklin Lakes, NY, USA). Every $24 \mathrm{~h}$, over a period of 5 days, cells were harvested and counted. The doubling time was estimated from the growth curves during the exponential phase of cells' growth.

Karyotyping analysis. The dividing cells, at the exponential growth phase (after 18 or $24 \mathrm{~h}$ ), were exposed to the colcemid solution $(0,25 \mu \mathrm{g} / \mathrm{ml}$ culture medium; Gibco; Thermo Fisher Scientific, Inc., Waltham, MA, USA) for $30 \mathrm{~min}$. Then, the cells were transferred into $10 \mathrm{ml}$ conical centrifuge tubes and centrifuged at $400 \mathrm{x} \mathrm{g}$ for $10 \mathrm{~min}$, after which the supernatant was removed and cells were suspended in 8-9 $\mathrm{ml}$ of prewarmed $\left(37^{\circ} \mathrm{C}\right)$ hypotonic solution $(20 \mathrm{mM}$ potassium chloride $(\mathrm{KCl})$ and $10 \mathrm{mM}$ sodium citrate $\left(\mathrm{Na}_{3} \mathrm{C}_{6} \mathrm{H}_{5} \mathrm{O}_{7} ; \mathrm{POCH}\right.$ S.A., Gliwice, Poland) with simultaneous vortexing. Next, the cells were incubated at $37^{\circ} \mathrm{C}$ for $30 \mathrm{~min}$ and centrifuged at $400 \mathrm{x} \mathrm{g}$ for $10 \mathrm{~min}$. The supernatant was removed without disrupting the pellets and cells were suspended in 8-9 $\mathrm{ml}$ cold $\left(4^{\circ} \mathrm{C}\right)$ fixative solution 3:1 (methanol:glacial acetic acid ratio) again with simultaneous vortexing. The fixation was repeated 3 times. Finally, cells were resuspended in 1-2 $\mathrm{ml}$ of fixative solution and about $0,3 \mathrm{ml}$ was dropped on a microscopic slide. The spread slides were dried for at least overnight at $37^{\circ} \mathrm{C}$ until staining. The G-banding was used as the routine cytogenetic technique. The metaphase chromosome staining was performed with gentle digestion in the trypsin solution $[0,25 \%$ in $1 \mathrm{X}$ phosphate-buffered saline (PBS), POCH S.A.] and the Giemsa stain (Sigma-Aldrich; Merck KGaA). The karyotypes for gastric adenocarcinoma cell lines were analyzed with the OLYMPUS BX51 microscope and the CytoVision Master 3.0 software (Olympus) according to the 2013 ISCN international guidelines (12).

Immunophenotyping. The following fluorescein (FITC)-, allophycocyanin (APC)-or phycoerythrin (PE)-conjugated mouse anti-human monoclonal antibodies (mAbs) were used: Anti-CD10, -CD11a, CD11c, -CD18, -CD33, -CD40, -CDD44std, -CD44v5, -CD44v6, -CD54, -CD61, -CD62P, -CD86, -CD133, -CD206 (MR), -EGFR, -Her-2/neu, -HLA-DR, HLA class I, -CCR5,-CCR6, Her-2/neu all from BD Pharmingen
(San Diego, CA, USA); anti-CD29, -CD36, -CD51, -CD58 from Immunotech (Marseille, France); anti-c-MET, -CCR1, -CCR2, -CCR3, -CCR7, -CXCR1, -CXCR2, -CXCR4 from R\&D (Abington, UK); anti-Tag72, -Mucin1 (EMA, CD227), -EMMPRIN from Santa Cruz Biotechnology, Inc. (Santa Cruz, CA, USA) and anti-Epithelial Antigen, -Epithelial Membrane Antigen (EMA) from DAKO (Heverlee, Belgium). Isotype controls included appropriate FITC-, APC- or PE-labeled mouse $\operatorname{IgG}_{1}, \operatorname{IgG}_{2 \mathrm{a}}$ or $\operatorname{IgG}_{2 \mathrm{~b}}$. Cells were incubated with $\mathrm{mAbs}$ or isotype controls for $20 \mathrm{~min}$ at $4^{\circ} \mathrm{C}$, washed, resuspended in PBS and analyzed by flow cytometry (FACS Canto; BD Biosciences Immunocytometry Systems, San Jose, CA, USA) using FACS DiVa software.

Western blotting. Cells were lysed in M-PER lysing buffer (Pierce; Thermo Fisher Scientific, Inc.) containing protease inhibitor cocktail (Roche). $20 \mu \mathrm{g}$ of isolated protein was mixed with NuPAGE LDS Sample Buffer (4X; Thermo Fisher Scientific, Inc.) and NuPAGE Sample Reducing Agent (10X; Thermo Fisher Scientific, Inc.). Samples were heated $\left(70^{\circ} \mathrm{C}, 10 \mathrm{~min}\right)$ and electrophoresed in $14 \%$ polyacrylamide gel containing SDS (Bio-Rad, Hercules, CA, USA). Next, electrophoresed samples were transferred onto the polyvinylidene fluoride membrane (Bio-Rad). Then, after blocking for $1 \mathrm{~h}$ at room temperature in Tris buffered saline (TBS) with 0,1\% Tween-20 (Sigma-Aldrich; Merck KGaA) and 1\% bovine serum albumin (BSA; Sigma-Aldrich; Merck KGaA), the membranes were incubated overnight at $4^{\circ} \mathrm{C}$ with the following antibodies: Goat anti-human ALDH1A1 (clone L-15), ALDH1A2 (clone N-20), ALDH1A3 (clone C-13), ALDH2 (clone N-14) and mouse anti-human ALDH3A1 (clone B-8), rabbit anti-EMMPRIN (clone N-19), -panCEA (clone: H-300), -MAGE-A1 (clone: FL-309) and -GAPDH (clone: 14C10) (all Santa Cruz Biotechnology, Dallas, TX, USA). As a loading control, rabbit anti-human GAPDH (Cell Signaling Technology, Inc., Danvers, MA, USA) was used. After incubation, membranes were washed in TBS supplemented with BSA and Tween-20 and incubated for $1 \mathrm{~h}$ at room temperature with either goat anti-rabbit or goat anti-mouse (dilution 1:4,000) secondary antibody conjugated with horseradish peroxidase (Santa Cruz Biotechnology, Inc.). The protein bands were visualized with the SuperSignal West Pico Chemiluminescence Substrate kit according to the manufacturer's protocol (Pierce; Thermo Fisher Scientific, Inc.) and analyzed with KODAK GEL LOGIC 1500 Digital Imaging System (KODAK, Rochester, NY, USA).

Detection of ALDH activity. The ALDEFLUOR kit (StemCells Technologies, Grenoble, France) was used for identification of cells with ALDH activity. Cells were incubated (45 $\mathrm{min}, 37^{\circ} \mathrm{C}$, final concentration $1 \times 10^{6} / \mathrm{ml}$ ) with the Assay Buffer containing BODIPY-amino-acetaldehyde (BAAA; final concentration $1 \mu \mathrm{M}$ )-a fluorescent substrate for ALDH. Cells able to process the BAAA substrate to its fluorescent form, BODIPY-aminoacetate (BAA), were considered as ALDH positive $\left(\mathrm{ALDH}^{+}\right)$. To confirm specificity of ALDH depended reaction cells were additionally incubated with specific ALDH inhibitor, diethylaminobenzaldehyde (DEAB). Cells incubated with DEAB only served as a negative control. After treatment, cells were washed and suspended in ice-cold 
Table I. Patients' characteristics.

\begin{tabular}{lcccl}
\hline Cells & Age & Gender & Stage (TNM) & Histology \\
\hline GC1401 & 72 & F & IV (T4NXM1) & Adenocarcinoma \\
GC1415 & 73 & M & IV (T4NXM1) & $\begin{array}{l}\text { Tubular adenocarcinoma combined with signet ring } \\
\text { cell carcinoma } \\
\text { GC1436 }\end{array}$ \\
\hline
\end{tabular}

F, female; M, Male.

PBS supplemented with $0.5 \%$ of BSA and verapamil $(50 \mu \mathrm{M}$; Sigma-Aldrich; Merck KGaA) to block Abcg2 transporters activity and prevent active efflux of the ALDEFLUOR product from viable cells.

Determination of Her-2/neu and MAGE-1, -2 mRNA expression in the cell lines using nested quantitative PCR ( $q P C R)$. The isolation of total RNA and qPCR for MAGE-1, -2 and $\beta$-actin was performed as previously described (13). For detection of HER-2/neu mRNA qPCR was performed using the following primers: Sense-5'-CCTCTGACGTCCATCATC TC-3' and antisense-5'-ATCTTCTCGTGCCGTCGCTT-3'. The cycle profile for HER-2/neu PCR run was: Initial denaturation at $95^{\circ} \mathrm{C}$ for $10 \mathrm{~min}$, then denaturation at $95^{\circ} \mathrm{C}$ for $0 \mathrm{sec}$, annealing at $60^{\circ} \mathrm{C}$ for $35 \mathrm{sec}$, and elongation at $72^{\circ} \mathrm{C}$ for $35 \mathrm{sec}$ for 35 cycles, followed by final extension at $72^{\circ} \mathrm{C}$ for $2 \mathrm{~min}$. The results were normalized with $\beta$-actin data and expressed as $C_{T}$. To verify amplified product, melting curve analysis using the LightCycler software was performed for each sample.

Xenografts in non-obese diabetic/severe combined immunodeficiency (NOD/SCID) mice. Cells $\left(1 \times 10^{6}\right.$ of each cell line, viability over $95 \%$ ) suspended in $200 \mu \mathrm{l}$ of saline were injected subcutaneously (s.c.) into dorsal region of 8 -week old NOD/SCID mice (5 mice per group; Charles River Laboratories, Sulzfeld, Germany). Every three days, tumor's diameter was measured with a caliper and its volume (v) was calculated according to the formula: $v=a b^{2} / 2$, where $\mathrm{a}$ is the longest dimension, $\mathrm{b}$ is the perpendicular width. When moribund, the tissues were examined macroscopically for metastasis in various organs and then processed for histological examination (14). The study was approved by the Ist Local Ethical Committee on Animal Testing (no. 128/2012).

Histological analysis. Subcutaneous GC1401, GC1415 and GC1436 tumors in NOD/SCID mice and other organs (spleen, liver, lung, lymph nodes) of tumor-bearing mice were cut out, divided into several portions and fixed in $10 \%$ buffered formalin. Some of them, after routine processing, were embedded in paraffin. $3 \mu \mathrm{m}$ thick sections were stained with $\mathrm{H} \& \mathrm{E}$ according to manufacturer's protocol.

Statistical analysis. The non parametric Kruskal-Wallis test was performed using GraphPad InStat version 4.0 software (GraphPad Software, Inc., La Jolla, CA, USA). P<0.05 was considered to indicate a statistically significant difference.

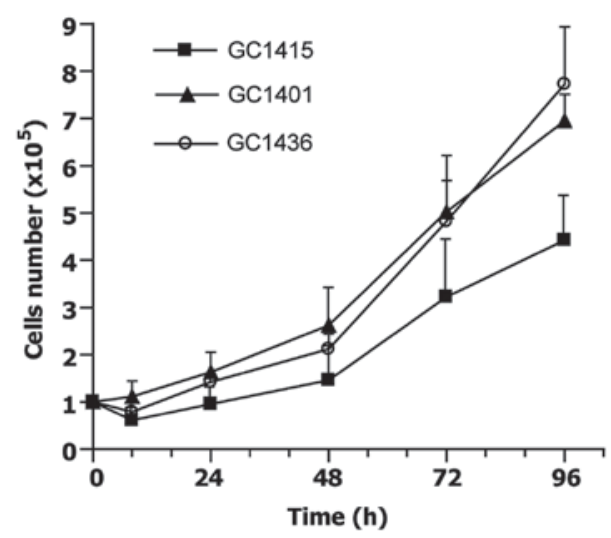

Figure 1. Growth curves of GC1401, GC1415 and GC1436 cell lines. Cells were cultured in duplicates and counted every $24 \mathrm{~h}$. The differences in doubling time were not statistically significant.

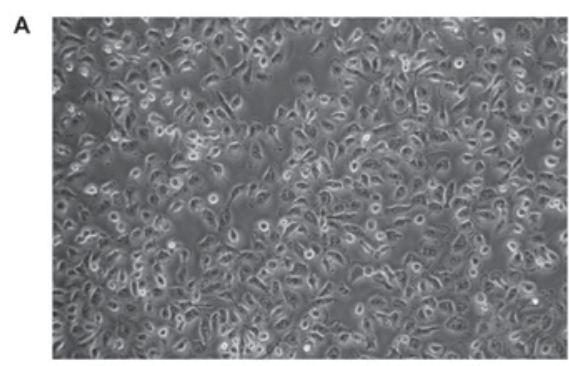

B

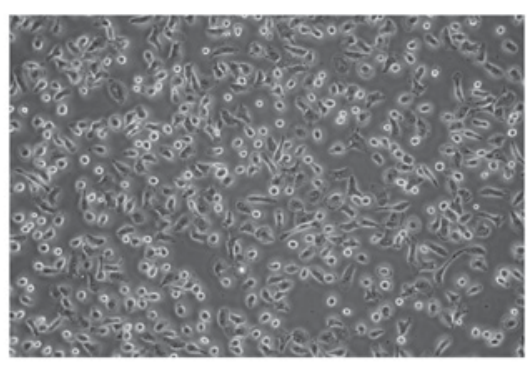

C

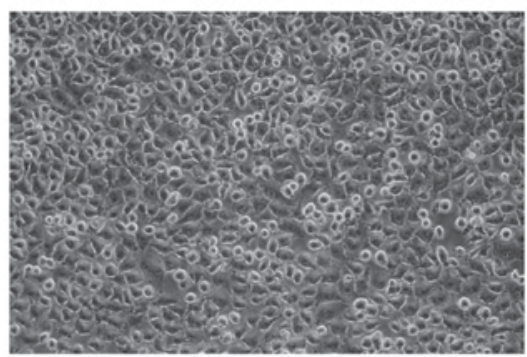

Figure 2. Phase-contrast photomicrographs of monolayers of (A) GC1401, (B) GC1415 and (C) GC1436 cell lines. Original magnification x400. 
Table II. Karyotypes of gastric adenocarcinoma cell lines.

Cell lines

Karyotype (ISCN 2013)

GC1401 52,X,+der(1)t(1;17?)(p13;q11.2?),dup(1)(p13p32),+2,der(6)t(6;17?)(p12;q11.2?),+der(7)t(7;?)(p11.2;?)?add(7) (q32?),+der(10)t(10;18?)(p11.2;p11.2?),der(12)t(12;14?)(q22;q22?),?dup(14)(q13q24),der(15)t(15;21?) (p13;q11.2?),der(16)?add(16) (q22 or q24),der(19)?add(19)(p13.3),rob(21;21)(q10;q10),+2mar[11]/52,X,+der(1) $\mathrm{t}(1 ; 17 ?)(\mathrm{p} 13 ; \mathrm{q} 11.2 ?), \operatorname{dup}(1)(\mathrm{p} 13 \mathrm{p} 32),+2, \operatorname{der}(6) \mathrm{t}(6 ; 17 ?)(\mathrm{p} 12 ; \mathrm{q} 11.2 ?),+\operatorname{der}(7) \mathrm{t}(7 ; ?)(\mathrm{p} 11.2 ; ?) ? \operatorname{add}(7)(\mathrm{q} 32 ?),+\operatorname{der}(10)$ $\mathrm{t}(10 ; 18 ?)(\mathrm{p} 11.2 ; \mathrm{p} 11.2 ?), \operatorname{der}(12) \mathrm{t}(12 ; 14$ ?)(q22;q22?),-13,?dup(14) (q13q24),der(15)t(15;21?)(p13;q11.2?), der(16)? $\operatorname{add}(16)(\mathrm{q} 22$ or q24),der(19)?add(19)(p13.3),rob(21;21)(q10;q10),+3mar[5]

GC1415 51-56,X,+der(1)t(1;17?)(p13;q11.2?),+2,+der(4)?(q),+5,der(6)t(6;17?)(p12;q11.2?),+7,-8,der(12)?add(12) (p13),? $\operatorname{dup}(14)(\mathrm{q} 13 \mathrm{q} 24), \operatorname{der}(15) \mathrm{t}(15 ; 21 ?)(\mathrm{p} 13 ; \mathrm{q} 11.2 ?), \operatorname{rob}(21 ; 21)(\mathrm{q} 10 ; \mathrm{q} 10),+\operatorname{mar}[\mathrm{cp} 7]$

Table III. Common chromosomal aberrations in gastric adenocarcinoma cell lines.

\begin{tabular}{llll}
\hline Cell lines & \multicolumn{1}{c}{ GC1401 } & \multicolumn{1}{c}{ GC1415 } & \multicolumn{1}{c}{ GC1436 } \\
\hline Ploidy & 52 chromosomes & $51-56$ chromosomes & $91-106$ chromosomes \\
Chromosomal aberrations & $+\operatorname{der}(1) \mathrm{t}(1 ; 17 ?)(\mathrm{p} 13 ; \mathrm{q} 11.2 ?)$ & $+\operatorname{der}(1) \mathrm{t}(1 ; 17 ?)(\mathrm{p} 13 ; \mathrm{q} 11.2 ?)$ & $+\operatorname{der}(1) \mathrm{t}(1 ; 17 ?)(\mathrm{p} 13 ; \mathrm{q} 11.2 ?)$ \\
& $\operatorname{dup}(1)(\mathrm{p} 13 \mathrm{p} 32)$ & & $\operatorname{dup}(1)(\mathrm{p} 13 \mathrm{p} 32)$ \\
& +2 & +2 & \\
& $\operatorname{der}(6) \mathrm{t}(6 ; 17 ?)(\mathrm{p} 12 ; \mathrm{q} 11.2 ?)$ & $\operatorname{der}(6) \mathrm{t}(6 ; 17 ?)(\mathrm{p} 12 ; \mathrm{q} 11.2 ?)$ & $\operatorname{der}(6) \mathrm{t}(6 ; 17 ?)(\mathrm{p} 12 ; \mathrm{q} 11.2 ?)$ \\
& $+\operatorname{der}(10) \mathrm{t}(10 ; 18 ?)(\mathrm{p} 11.2 ; \mathrm{p} 11.2 ?)$ & & $\operatorname{der}(10) \mathrm{t}(10 ; 18 ?)(\mathrm{p} 11.2 ; \mathrm{p} 11.2 ?)$ \\
& & $\operatorname{der}(12) ? \mathrm{add}(12)(\mathrm{p} 13)$ & $\operatorname{der}(12) ? \mathrm{add}(12)(\mathrm{p} 13)$ \\
& $\operatorname{der}(12) \mathrm{t}(12 ; 14 ?)(\mathrm{q} 22 ; \mathrm{q} 22 ?)$ & & $\operatorname{der}(12) \mathrm{t}(12 ; 14 ?)(\mathrm{q} 22 ; \mathrm{q} 22 ?)$ \\
& $? \operatorname{dup}(14)(\mathrm{q} 13 \mathrm{q} 24)$ & $? \operatorname{dup}(14)(\mathrm{q} 13 \mathrm{q} 24)$ & $? \operatorname{dup}(14)(\mathrm{q} 13 \mathrm{q} 24)$ \\
& $\operatorname{der}(15) \mathrm{t}(15 ; 21 ?)(\mathrm{p} 13 ; \mathrm{q} 11.2 ?)$ & $\operatorname{der}(15) \mathrm{t}(15 ; 21 ?)(\mathrm{p} 13 ; \mathrm{q} 11.2 ?)$ & \\
& $\operatorname{der}(19) ? \mathrm{add}(19)(\mathrm{p} 13.3)$ & & $\operatorname{der}(19) ? \operatorname{add}(19)(\mathrm{p} 13.3)$ \\
& $\operatorname{rob}(21 ; 21)(\mathrm{q} 10 ; \mathrm{q} 10)$ & $\operatorname{rob}(21 ; 21)(\mathrm{q} 10 ; \mathrm{q} 10)$ & $\operatorname{rob}(21 ; 21)(\mathrm{q} 10 ; \mathrm{q} 10)$ \\
\hline
\end{tabular}

\section{Results}

Growth characteristics. The cells were obtained from carcinomatous ascites of patients diagnosed with gastric adenocarcinoma (Table I). All patients were evaluated as non-resectable, with peritoneal spread and no liver or lung metastases.

At the initiation of the culture, some of the cells adhered to the plastic surface, while the others did not. In the case of GC1401 and GC1415 cells, negligible proliferation of tumor cells was observed for several (6-8) weeks, instead, the proliferation of fibroblasts was seen. After this period of adaptation to the in vitro conditions, both GC1401 and GC1415 cells started to grow rapidly. In contrast, the GC1436 cells were rapidly growing from the beginning. With successive passages, the number of fibroblasts gradually decreased, to be finally replaced by tumor cells. Doubling time, estimated at exponential phase of growth, for GC1401 and GC1415 cell lines was about 30 and 34 h, respectively, and about $25 \mathrm{~h}$ for GC1436 cells (Fig. 1). The differences in doubling time were not significant. All cells exhibited morphologic features of epithelial-like cells, creating the sheets of polygonal cells which attached to the culture flask and formed monolayer at confluence (Fig. 2).

Karyotyping. Karyotyping analysis showed a great complexity of all three gastric adenocarcinoma cell lines. The identified variety involves especially structural chromosomal aberrations. Additionally, high hyperdiploidy of tumor cell lines were detected; from 51-56 and 52 chromosomes for GC1415 and GC1401 to 91-106 chromosomes for GC1436. The best cytogenetic characterization was done for the GC1401 cell line, because of the presence of only two subclones (Table II). The karyotype description according to the international guidelines was also possible for this cell line. The exact result for the GC1436 cell line was not allowed due to high heterogeneity of the cells and a low resolution of the karyotype. Additionally, several structural and numerical chromosomal abnormalities were evident in all cell lines (Table III).

Expression of surface determinants. The expression of surface determinants on cells from in vitro cultures was evaluated using a wide range of mAbs (Table IV). All three cell lines showed a similar pattern of surface determinants with similar levels of expression. All cell lines were HLA-class I positive (100\% of cells) and HLA-DR negative. CD29 and CD51 integrins and CD58 of the Ig superfamily were expressed on all cells. The majority of GC1401, GC1415 and GC1436 cells possessed the expression of CD10, CD40, CD44 and CD61 determinants. There were differences between the cell lines in the expression of CD44 variants. The lowest level of v5 and v6 was noticed on GC1401 cells (about 3 and 34\%, respectively). GC1415 cells were positive in $\sim 10 \%$ for the v5 and in $\sim 50 \%$ 
Table IV. Expression of selected surface markers on gastric adenocarcinoma cell lines.

\begin{tabular}{|c|c|c|c|}
\hline Surface marker & $\begin{array}{c}\text { GC1401 } \\
\text { (\% of cells) }\end{array}$ & $\begin{array}{c}\text { GC1415 } \\
\text { (\% of cells) }\end{array}$ & $\begin{array}{c}\text { GC1436 } \\
\text { (\% of cells) }\end{array}$ \\
\hline CD10 & 50 & $70-80$ & $80-90$ \\
\hline CD29 & 100 & $97-100$ & 100 \\
\hline CD33 & 1 & 8 & 9 \\
\hline CD40 & $91-99$ & $85-100$ & $65-85$ \\
\hline CD44 & $92-97$ & $88-93$ & $79-83$ \\
\hline CD44v5 & 3 & 10 & 41 \\
\hline CD44v6 & $24-44$ & $38-70$ & $48-80$ \\
\hline CD51 & 100 & $95-99$ & $96-99$ \\
\hline CD58 & 100 & $89-99$ & $92-100$ \\
\hline CD61 & $90-95$ & $87-97$ & 97 \\
\hline CD86 & $11-20$ & $12-17$ & $13-18$ \\
\hline HLA-ABC & 100 & 100 & 100 \\
\hline CCR3 & 3 & 10 & 3 \\
\hline CCR6 & $6-15$ & 10 & 10 \\
\hline CCR7 & 2 & $1-2$ & 1 \\
\hline CXCR1 & 5 & 3 & 3 \\
\hline CXCR4 & $2-3$ & $3-4$ & 3 \\
\hline c-MET & 98 & 97 & 98 \\
\hline Her-2/neu & $63-98$ & $92-98$ & 98 \\
\hline Tag72 & 0 & 0 & $2-3$ \\
\hline Epithelial Antigen & 0 & $4-7$ & $2-9$ \\
\hline Mucin1(CD227) & $2-4$ & $4-7$ & $5-14$ \\
\hline EMMPRIN & $7-17$ & $26-66$ & $16-24$ \\
\hline
\end{tabular}

CD11a, CD11c, CD18, CXCR2, CCR1, CCR2, CCR5, CD206, HLA-DR, CD133, CD62P, CD54, CD36 were not detected.

positive for the v6. The highest level of the v5 (app. 40\%) and the v6 (app. 60\%) positive cells was among GC1436 cells. Less than $10 \%$ of cells were positive for CD33 and 10-20\% were positive for CD86. The other determinants tested (i.e., CD11a, c, CD18, CD36, CD54, CD62P, CD133, CD206) were not detected on the cells of all three cell lines.

The cells were comparably positive for CCR3 expression which fluctuated between 5 to $25 \%$ of positive cells and CCR6 was present on $6-15 \%$ of cells. Very low percent of CCR7 (1-2\%), CXCR1 and CXCR4 (up to 5\%) and the lack of CCR1, 2, 5, and CXCR2 expression was observed on cells of all cell lines.

The highest level of EMMPRIN positive cells was observed in GC1415 cell line (up to 66\%), whereas GC1401 and GC1436 cell lines were up to $24 \%$ positive. These results corroborate with western blotting data where EMMPRIN was shown to be present in all three cell lines (Fig. 3). Mucin1 (EMA) was detected on a small population of GC1401, GC1415 and GC1436 cells (below 14\%). Almost all cells of the three cell lines were Her-2/neu and c-MET positive. Tag72 was detected on a very low percent (app. 3\%) of GC1436 cells and was not present on GC1401 and GC1415 cells. Epithelial Antigen was detected on GC1415 and GC1436, however, the percentage of positive cells was very low (less than $9 \%$ of cells). Presence of panCEA was

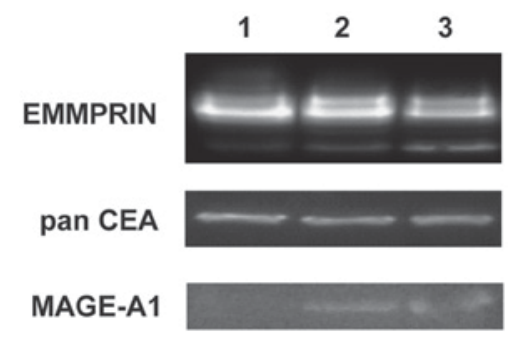

Figure 3. Expression of EMMPRIN, panCEA and MAGE-A1 in gastric cell line detected by Western blotting. 1-GC1401, 2-GC1415 and 3-GC1436. Lane 1, GC1401; lane 2, GC1415; and lane 3, GC1436.

confirmed by western blotting in all tested cell lines. Expression of MAGE-1 was detected by western blotting in GC1415 and 1436 only (Fig. 3).

Expression and activity of ALDH. ALDH expression was assessed by western blotting. All three tested cell lines expressed ALDH1A3 and ALDH2 isoforms, however, none of them expressed ALDH1A1, ALDH1A2 and ALDH3A1 isoforms (Fig. 4A). The ALDH activity measured by flow cytometry was very low (Fig. 4B); less than $1 \%$ of cells showed such activity. This observation is consistent with the data that ALDH1A1 is the main enzyme of the ALDH family responsible for the enzymatic activity as determined by the ALDEFLUOR assay.

Determination of MAGE-1, -2 and Her-2/neu mRNA expression by nested $q P C R$. In all three tumor cell lines similar amounts of mRNA for MAGE-1, -2 and Her-2/neu were detected. To verify the amplified product, melting curve analysis was performed for each sample confirming the presence of MAGE-1 mRNA and Her-2/neu (respectively Fig. 5).

Tumorigenicity and metastasis evaluation. All three cell lines were tumorigenic in vivo in NOD/SCID mice. The transplantation of cells from in vitro culture led usually to the formation of tumors in 13 of 15 mice ( 82-89\%). Following s.c. injection of $1 \times 10^{6}$ tumor cells, palpable encapsulated tumors were observed within 3-4 weeks (Fig. 6). The differences in tumor growth were not statistically significant. $100 \%$ mortality was noticed at week 13. Fig. 7 presents hematoxylin-eosin staining of the tumor sections after 8 weeks of the tumor growth in vivo. Histologically in all cases malignant neoplasm of epithelial origin was observed.

No macro- and microscopic metastasis to lungs, liver, peritoneum, spleen, kidneys or lymph nodes were observed.

\section{Discussion}

There are GC cell lines already established and characterized, however, due to the heterogeneity of cancer cells each newly characterized cell line may provide new data useful for anticancer therapy. The presented manuscript describes the characterization of three new cell lines established from the malignant ascites of Caucasian patients diagnosed with gastric adenocarcinoma. The use of primary tumors as a source of cancer cells encounters several problems, e.g., the need for mechanical or enzymatic disruption which often leads to cell 


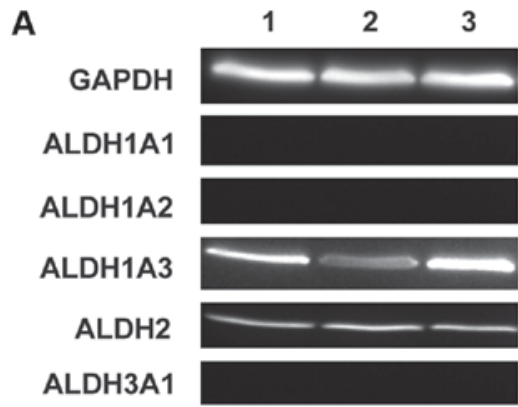

B

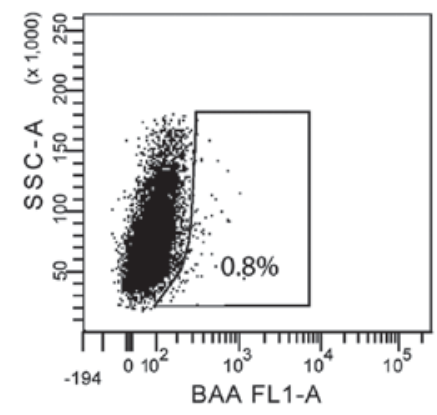

GC1401

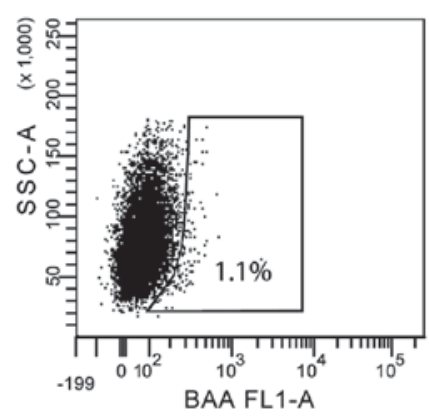

GC1415 + DEAB

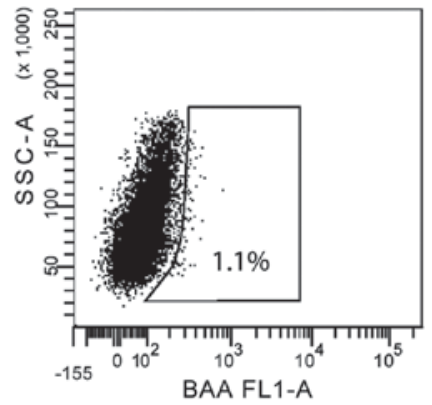

GC1415

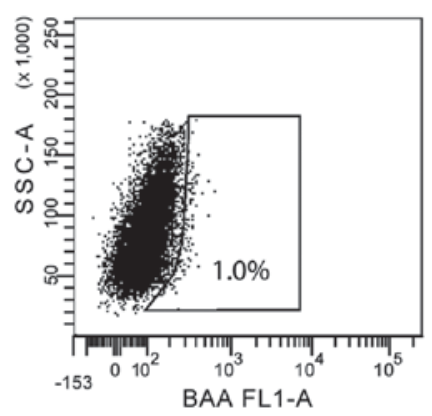

GC1436 + DEAB

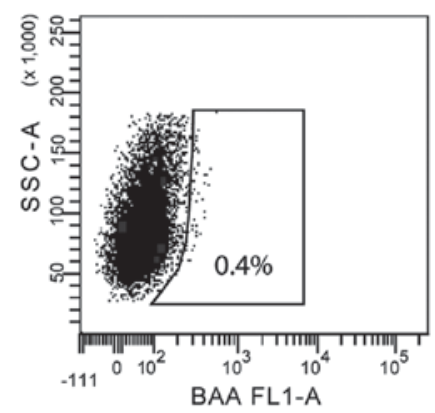

GC1436

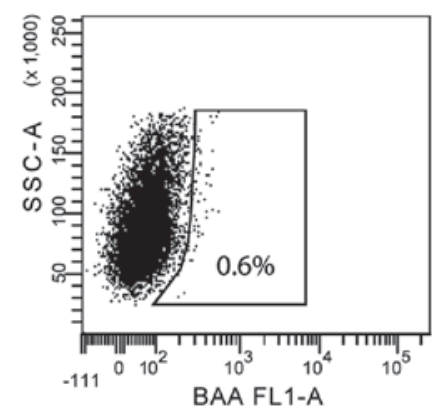

Figure 4. Aldehyde dehydrogenase (ALDH) protein activity and expression in gastric cancer (GC) cell lines. (A) Western blot analysis was used to compare the expression of different ALDH isozymes GC1401 (lane 1), GC1415 (lane 2) and GC1436 (lane 3) GC cell lines. GAPDH served as loading control. (B) ALDH activity in GC cell lines. Flow cytometric graphs show the fluorescence intensity of reacted ALDH substrate in the absence and presence of diethylaminobenzaldehyde (DEAB), a specific ALDH inhibitor. Gated regions indicated $\mathrm{ALDH}^{+}$cells.

damage, which is not the case, when ascites is being used. Also, the addition of autologous ascitic fluid improves the culture conditions and cell survival (especially at the beginning), which is probably due to the presence of growth-promoting factors (15). Doubling time of established cell lines fall in the range described for commercially available GC cell lines e.g., KATO, ATCC ${ }^{\circledR} \mathrm{HTB}-103$, ATCC ${ }^{\circledR} \mathrm{CRL}-5973$ and ATCC ${ }^{\circledR}$ CRL-5973 (21-36 h) (16).

Based on karyotyping analysis, a great cytogenetic complexity in the investigated cell lines was observed. Numerous structural and ploidy aberrations were evident in all three cell lines. This observation is in accordance with high ploidies of well-defined human stomach-derived cell lines in the American Type Culture Collection which are mostly hypotetraploid (ATCC ${ }^{\circledR} \mathrm{HTB}-103$, ATCC ${ }^{\circledR}$ CRL-5973, ATCC ${ }^{\circledR}$ CRL-5974). To the authors' best knowledge, all of the identified chromosomal changes are reported for the first time, and will be subjected to further research. It has been indicated that $53-94 \%$ of advanced gastric adenocarcinomas have an abnormal chromosomal number $(17,18)$. The chromosomal alterations have been recorded in gastric adenocarcinomas as gains: 1q, 3q, 7p, 7q, 8q, 9q, 10p, 11q, 13q, 17q, 19q, 20q and losses: 1p, 4p, 4q, 5q, 6q, 9p, 10, 13, 17p, 18q (19-25). The double minute chromosomes were not found in GC cell lines, but were described in ATCC ${ }^{\circledR}$ CRL-5971, ATCC ${ }^{\circledR}$ CRL-5973 and ATCC ${ }^{\circledR}$ CRL-5974 (but not KATO-III). Additionally, aneuploidy has been detected as a potentially unfavorable prognostic marker often associated with high proliferative activity and metastatic potential $(17,18)$.

A complex karyotype is often reported in aggressive cancers with a tendency to metastasize (26-28). The structural rearrangements are one of the activation modes of protooncogenes and may also be a reason for suppressor genes inactivation, which in turn may induce and drive the neoplastic process. The classical karyotyping has limitations, primarily with the resolution of the study and the quality of metaphase chromosomes. Nevertheless, conventional banding remains the best technique for the evaluation balanced aberrations.

The phenotype analysis revealed the presence of HLA class I, CD40 (member of TNFR superfamily) and some 

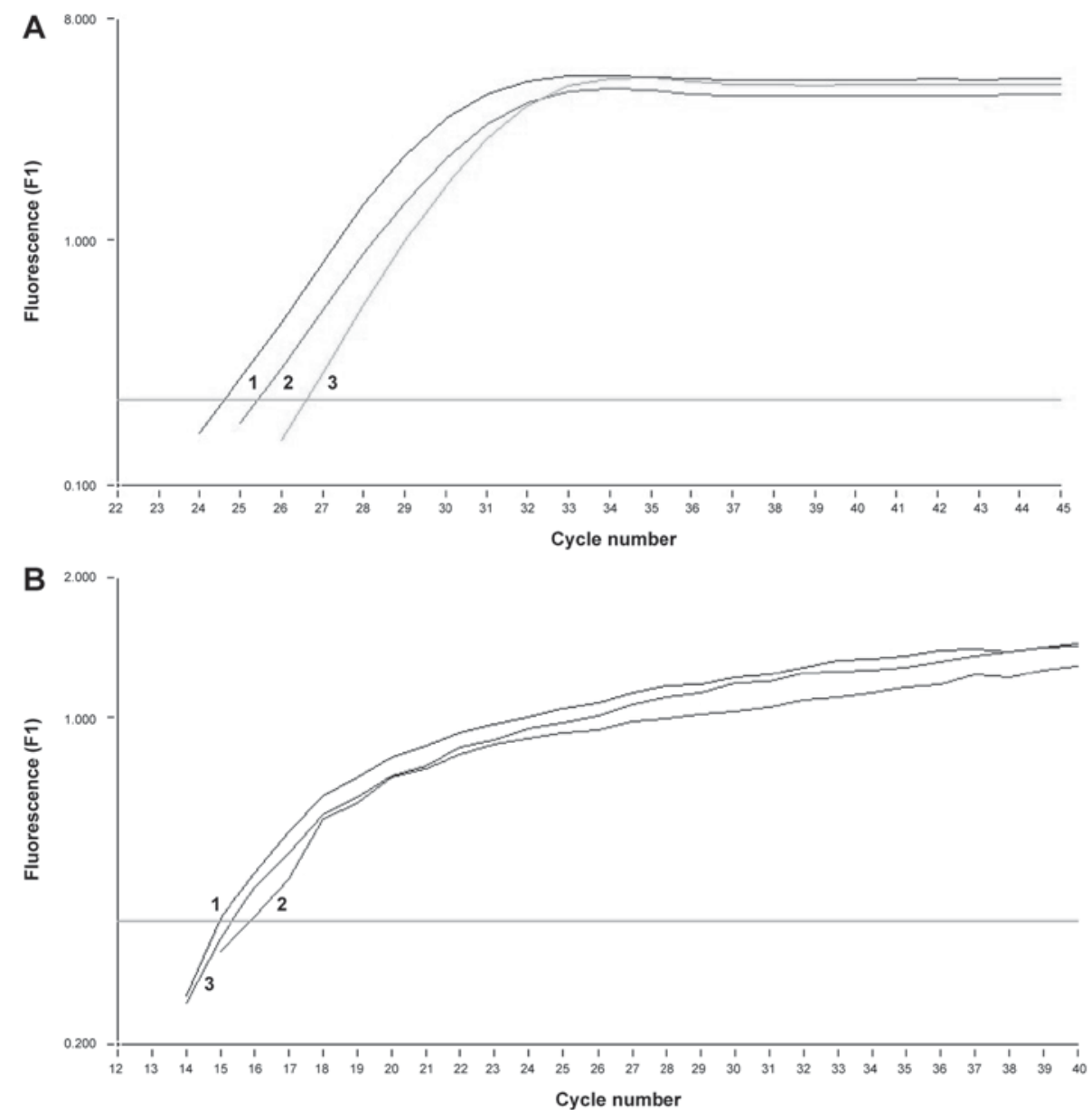

Figure 5. Expression of mRNA for tumor markers: (A) Her-2/neu and (B) MAGE-1 in GC1401 (1), GC1415 (2), GC1436 (3) tumor cells. Negative control is out of scale. One representative experiment of 3 performed is presented.

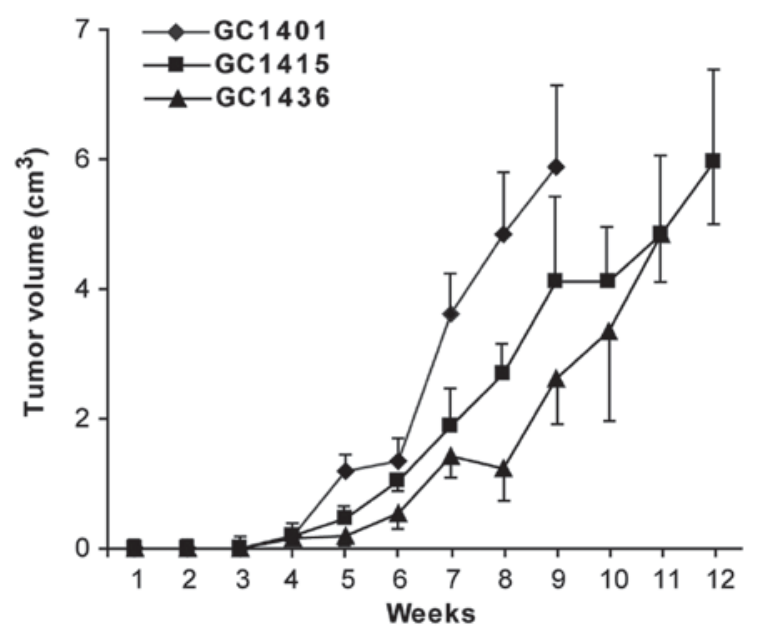

Figure 6. Tumor growth of GC1401, GC1415 and GC1436 cells in NOD/SCID mice. Tumor volume was calculated every 3 days and presented in time relation. One experiment of two performed is shown. The observed differences were not statistically significant. NOD/SCID, non-obese diabetic/severe combined immunodeficiency.

adhesion molecules of the Ig superfamily (CD58), integrins (CD29, CD51, CD61) and CD44 on almost all cells of all three cell lines. The level of these markers did not change throughout the culture. CD44 variants 5 and 6 were also
A

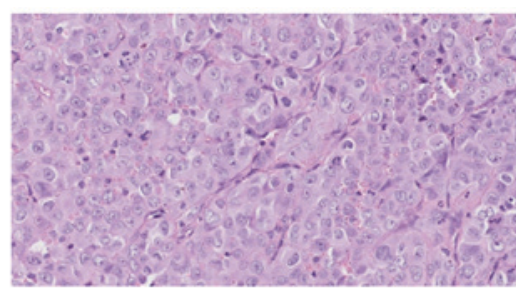

B

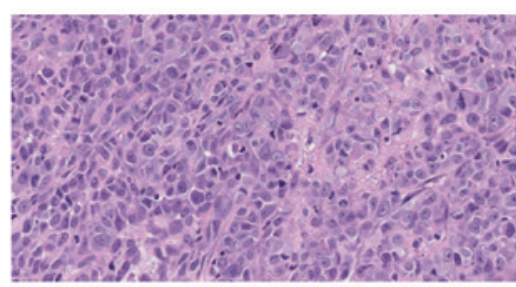

C

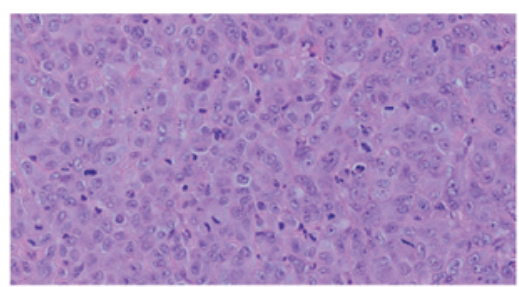

Figure 7. Subcutaneous injection of GC cells into NOD/SCID mice led to primary tumor development at the site of injection. Histological analysis of section stained with hematoxylin and eosin of tumor established in NOD/SCID is presented (A) GC1401, (B) GC1415 and (C) GC1436. Magnification x200. NOD/SCID, non-obese diabetic/severe combined immunodeficiency. 
present, but their expression has varied in the course of culture. These markers were already detected in solid tumors including GC as well as GC cell lines (e.g., KATO-III, SNU-5, SNU-16) (29,30). Their high expression was observed in more expanding tumors (31) and was correlated with decreased patients' survival (32-35).

Among chemokine receptors, CCR3, CCR6, CCR7, CXCR1 and CXCR4 were present at very low levels on the cells of all cell lines. Chemokine receptors are involved in different activities of tumor cells such as migration, invasion and adhesion and their high levels are usually associated with an aggressive character of tumor cells. The presence of the above receptors was described on different cancer cells of the gastrointestinal duct, including GC $(36,37)$, and they were usually upregulated during metastasis (38-42).

The level of mucin-positive cells was low (3\% of GC1401, $5 \%$ of $\mathrm{GC} 1415$ and $10 \%$ of GC1436). At the same time CD10 expression was relatively high and varied from $50 \%$ in GC1401 to $80 \%$ in GC1415 and up to $90 \%$ in GC1436 cells. Previously, expression of CD10 was observed in KATO-III cell line (43). Recently, combined expression of CD10 and MUC was employed to distinguished between gastric and an intestinal types of GC $(44,45)$. According to this classification, the expression of CD10 and the absence of MUC-1 (or other proteins from MUC family) may suggest intestinal type of GC. Moreover, expression of c-MET and Her-2 may also confirm this histological type (46). c-MET and Her-2/neu, the members of receptor tyrosine kinase family, involved in tumor growth and survival, were present on all cells of each cell line, as detected at both the protein and mRNA level. Their overexpression is usually associated with tumor metastasis and poor prognosis $(47,48)$. Strong expression of EMMPRIN as described by Zheng et al (49), may contribute to enhanced growth, invasion and angiogenesis of gastric carcinoma. New, EMMPRIN-positive cell lines, may help to evaluate the angiogenesis process.

One of the intriguing questions in this study was the lack of in vivo metastasis in NOD/SCID mice after subcutaneous engrafting of cancer cells. It has been already observed that although human cancer cells proliferate after injection into nude or SCID mice and form tumors in situ, their ability to form local or distal metastases is rare $(50,51)$. In the case of the presented GC cell lines the lack of metastasis may have arisen from several reasons:

i) Heterotopic human-mice model of subcutaneous engraftment of human GC in NOD/SCID mice did not reconstruct the conditions for growth and metastasis of human cancer in human microenvironment (52).

ii) Presence of a capsule may hamper metastasis (53).

iii) Low levels or lack of important agents, such as cytokines/chemokines and/or their receptors (e.g., low expression of chemokine receptors in the case of presented GC cell lines).

iv) Lack of or very low level of cancer stem cells (CSC) (presented GC cell lines express CD44 but lack the expression of CD54 (54) or $\mathrm{CD}^{3} 33^{+}$(55) markers characteristic for CSC).

v) Very low levels of ALDH activity. The expression of ALDH1A3 and ALDH2 was detected by western blotting assay, but surprisingly very low amount of cells (app. 1\%) exhibiting ALDH activity, as judged by the ALDEFLUOR assay, were observed. This may be due to the lack of ALDH1A1 and ALDH1A2 which are potentially major contributors of ALDH1 activity in different types of cancer e.g., breast and lung cancer $(56,57)$.

Many studies have shown elevated expression of ALDH isoforms other than ALDH1A1, but they do not directly prove that they are the cause of ALDEFLUOR activity in cancers (58-61).

The role of the ALDH1A3 isoform in GC progression still needs to be elucidated. High levels of this protein were observed in normal stomach tissue, however, its mRNA overexpression was detected in patients with GC, and was correlated with worse patient survival (62). ALDH2 is constitutively expressed in a variety of tissues (63), however, its role in tumor progression is limited to genetic polymorphism (rs671) and correlated with alcohol consumption (64). Our data may suggest that the low, but noticeable, activity of ALDH may come from ALDH1A3 or ALDH2 isoforms, which may play a role in tumorigenesis in a tissue-specific manner.

In summary, cancer metastasis is a complicated, multi-step process, influenced by many factors. Despite the presence of some prometastatic determinants (eg. CD29, CD40, CD44, c-MET, Her-2/neu, composed karyotype) and soluble factors such as IL-8, VEGF (data not shown), the lack of others (chemokine receptors, insufficient levels of CSC, activity of ALDH1A1) may disrupt the progression of metastasis leading to its inhibition.

The mortality of GC is very high due to its high heterogeneity even within the same tumor where cell subpopulations may show a diverse potential to growth and metastasis. In consequence, conventional therapies are not fully effective, as subpopulations of cells may differ in response to them. Three novel cell lines, established and characterized in our laboratory, may provide models for studies on biological heterogeneity of human GC cells.

\section{Acknowledgements}

This study was supported by the National Science Centre (grant no. UMO-2012/07B/NZ6/03499).

\section{References}

1. Torre LA, Bray F, Siegel RL, Ferlay J, Lortet-Tieulent J and Jemal A: Global cancer statistics, 2012. CA Cancer J Clin 65: 87-108, 2015

2. Verdecchia A, Santaquilani M and Sant M: Survival for cancer patients in Europe. Ann Ist Super Sanita 45: 315-324, 2009.

3. Fidler IJ: Biological heterogeneity of cancer: Implication to therapy. Hum Vaccines Immunother 8: 1141-1142, 2012.

4. Kato M, Shimada Y, Tanaka H, Hosotani R, Ohshio G, Ishizaki K and Imamura M: Characterization of six cell lines established from human pancreatic adenocarcinomas. Cancer 85: 832-840, 1999.

5. Park JG, Frucht H, LaRocca RV, Bliss DP Jr, Kurita Y, Chen TR, Henslee JG, Trepel JB, Jensen RT, Johnson BE, et al: Characteristics of cell lines established from human gastric carcinoma. Cancer Res 50: 2773-2780, 1990.

6. Chun YH, Kil JI, Suh YS, Kim SH, Kim H and Park SH: Characterization of chromosomal aberrations in human gastric carcinoma cell lines using chromosome painting. Cancer Genet Cytogenet 119: 18-25, 2000.

7. Croker AK, Goodale D, Chu J, Postenka C, Hedley BD, Hess DA and Allan AL: High aldehyde dehydrogenase and expression of cancer stem cell markers selects for breast cancer cells with enhanced malignant and metastatic ability. J Cell Mol Med 13: 2236-2252, 2009. 
8. Liao J, Qian F, Tchabo N, Mhawech-Fauceglia P, Beck A, Qian Z, Wang X, Huss WJ, Lele SB, Morrison CD and Odunsi K: Ovarian cancer spheroid cells with stem cell-like properties contribute to tumor generation, metastasis and chemotherapy resistance through hypoxia-resistant metabolism. PLoS One 9: e84941, 2014

9. Mu X, Patel S, Mektepbayeva D, Mahjoub A, Huard J and Weiss K: Retinal targets ALDH positive cancer stem cell and alters the phenotype of highly metastatic osteosarcoma cells Sarcoma 2015: 784954, 2015

10. Ajani JA, Wang X, Song S, Suzuki A, Taketa T, Sudo K, Wadhwa R, Hofstetter WL, Komaki R, Maru DM, et al: ALDH-1 expression levels predict response or resistance to preoperative chemoradiation in resectable esophageal cancer patients. Mol Oncol 8: 142-149, 2014

11. Li XS, Xu Q, Fu XY and Luo WS: ALDH1A1 overexpression is associated with the progression and prognosis in gastric cancer. BMC Cancer 14: 705, 2014.

12. Schafer LG, McGowan-Jordan J and Schmid M (eds): ISCN 2013: An International System for Human Cytogenetic Nomenclature. S. Karger, Basel, 2013.

13. Szatanek R, Drabik G, Baran J, Kolodziejczyk P, Kulig J, Stachura $\mathbf{J}$ and Zembala M: Detection of isolated tumor cells in the blood and bone marrow of patients with gastric cancer by combined sorting, isolation and determination of MAGE-1, -2 mRNA expression. Oncol Rep 19: 1055-1060, 2008

14. Iwanuma Y, Chen FA, Egilmez NK, Takita $\mathrm{H}$ and Bankert RB: Antitumor immune response of human peripheral blood lymphocytes coengrafted with tumor into severe combined immunodeficient mice. Cancer Res 57: 2937-2942, 1997.

15. Alama A, Barbieri F, Favre A, Cagnoli M, Noviello E, Pedullà F, Viale M, Foglia G and Ragni N: Establishment and characterization of three new cell lines derived from the ascites of human ovarian carcinomas. Gynecol Oncol 62: 82-88, 1996.

16. Birsoy K, Possemato R, Lorbeer FK, Bayraktar EC, Thiru P, Yucel B, Wang T, Chen WW, Clish CB and Sabatini DM: Metabolic determinants of cancer cell sensitivity to glucose limitation and biguanides. Nature 508: 108-112, 2014

17. Doak SH: Aneuploidy in upper gastro-intestinal tract cancers-a potential prognostic marker? Mutat Res 651: 93-104 2008.

18. Leal MF, Martins do Nascimento JL, da Silva CE, Vita Lamarão MF, Calcagno DQ, Khayat AS, Assumpção PP, Cabral IR, de Arruda Cardoso Smith M and Burbano RR: Establishment and conventional cytogenetic characterization of three gastric cancer cell lines. Cancer Genet Cytogenet 195: 85-91, 2009.

19. Buffart TE, Carvalho B, Mons T, Reis RM, Moutinho C, Silva P, van Grieken NC, Vieth M, Stolte M, van de Velde CJ, et al: DNA copy number profiles of gastric cancer precursor lesions. BMC Genomics 8: 345, 2007.

20. David S and Meltzer SJ: Stomach-genetic and epigenetic alterations of preneoplastic and neoplastic lesions. Cancer Biomark 9: 493-507, 2010

21. Kimura Y, Noguchi T, Kawahara K, Kashima K, Daa T and Yokoyama S: Genetic alterations in 102 primary gastric cancers by comparative genomic hybridization: Gain of $20 \mathrm{q}$ and loss of $18 \mathrm{q}$ are associated with tumor progression. Mod Pathol 17: $1328-1337,2004$

22. Wu CW, Chen GD, Fann CS, Lee AF, Chi CW, Liu JM, Weier U and Chen JY: Clinical implications of chromosomal abnormalities in gastric adenocarcinomas. Genes Chromosom Cancer 35 219-231, 2002

23. Koo SH, Kwon KC, Shin SY, Jeon YM, Park JW, Kim SH and Noh SM: Genetic alterations of gastric cancer: Comparative genomic hybridization and fluorescence In situ hybridization studies. Cancer Genet Cytogenet 117 97-103, 2000

24. Sakakura C, Hagiwara A, Taniguchi H, Yamaguchi $T$, Yamagishi H, Takahashi T, Koyama K, Nakamura Y, Abe T and Inazawa J: Chromosomal aberrations in human hepatocellular carcinomas associated with hepatitis $C$ virus infection detected by comparative genomic hybridization. Br J Cancer 80 : 2034-2039, 1999.

25. Stocks S, Pratt N, Sales M, Johnston DA, Thompson AM, Carey FA and Kernohan NM: Chromosomal imbalances in gastric and esophageal adenocarcinoma: Specific comparative genomic hybridization-detected abnormalities segregate with junctional adenocarcinomas. Genes Chromosomes Cancer 32: 50-58, 2001
26. Göhring G, Michalova K, Beverloo HB, Betts D, Harbott J, Haas OA, Kerndrup G, Sainati L, Bergstraesser E, Hasle H, et al: Complex karyotype newly defined: The strongest prognostic factor in advanced childhood myelodysplastic syndrome. Blood 116: 3766-3769, 2010.

27. Orozco JJ and Appelbaum FR: Unfavorable, complex, and monosomal karyotypes: The most challenging forms of acute myeloid leukemia. Oncology (Williston Park) 26: 706-712, 2012.

28. Höglund M, Frigyesi A, Säll T, Gisselsson D and Mitelman F: Statistical behavior of complex cancer karyotypes. Genes Chromosomes Cancer 42: 327-341, 2005.

29. Sakakura C, Hagiwara A, Nakanishi M, Shimomura K, Takagi T, Yasuoka R, Fujita Y, Abe T, Ichikawa Y, Takahashi S, et al: Differential gene expression profiles of gastric cancer cells established from primary tumour and malignant ascites. Brit J Cancer 87: 1153-1161, 2002

30. Washington K, Gottried MR and Telen MJ: Expression of the cell adhesion molecule CD44 in gastric adenocarcinomas. Hum Pathol 25: 1043-1049, 1994.

31. Yamaguchi K, Ura H, Yasoshima T, Shishido T, Denno R and Hirata K: Establishment and characterization of a human gastric carcinoma cell line that is highly metastatic to lymph nodes. J Exp Clin Cancer Res 19: 113-120, 2000.

32. Mayer B, Lorenz C, Babic R, Jauch KW, Schildberg FW, Funke I and Johnson JP: Expression of leukocyte cell adhesion molecules on gastric carcinomas: Possible involvement of LFA-3 expression in the development of distant metastases. Int J Cancer 64: 415-423, 1995

33. Wakatsuki K, Yamada Y, Narikiyo M, Ueno M, Takayama T, Tamaki H, Miki K, Matsumoto S, Enomoto K, Yokotani T and Nakajima Y: Clinicopathological and prognostic significance of mucin phenotype in gastric cancer. J Surg Oncol 98: 124-129, 2008.

34. Xin Y, Grace A, Gallagher MM, Curran BT, Leader MB and Kay EW: CD44V6 in gastric carcinoma: A marker of tumor progression. Appl Immunohistochem Mol Morphol 9: 138-142, 2001.

35. Chen J, Zhou J, Lu J, Xiong H, Shi X and Gong L: Significance of CD44 expression in head and neck cancer: A systemic review and meta-analysis. BMC Cancer 14: 15, 2014.

36. Ohtani H, Nakayama T and Yoshie O: In situ expression of the CCL20-CCR6 axis in lymphocyte-rich gastric cancer and its potential role in the formation of lymphoid stroma. Pathol Int 61: 645-651, 2011.

37. Arigami T, Natsugoe $S$, Uenosono $Y$, Yanagita $S$, Arima $H$, Hirata M, Ishigami S and Aikou T: CCR7 and CXCR4 expression predicts lymph node status including micrometastasis in gastric cancer. Int J Oncol 35: 19-24, 2009.

38. Jöhrer K, Zelle-Rieser C, Perathoner A, Moser P, Hager M, Ramoner R, Gander H, Höltl L, Bartsch G, Greil R and Thurnher M: Up-regulation of functional chemokine receptor CCR3 in human renal cell carcinoma. Clin Cancer Res 11: 2459-2465, 2005

39. Rubie C, Oliveira V, Kempf K, Wagner M, Tilton B, Rau B, Kruse B, Konig J and Schilling M: Involvement of chemokine receptor CCR6 in colorectal cancer metastasis. Tumor Biol 27: 166-174, 2006.

40. Koizumi K, Hojo S, Akashi T, Yasumoto K and Saiki I: Chemokine receptors in cancer metastasis and cancer cell-derived chemokines in host immune response. Cancer Sci 98: 1652-1658, 2007.

41. Sugasawa H, Ichikura T, Tsujimoto H, Kinoshita M, Morita D, Ono S, Chochi K, Tsuda K, Seki S and Mochizuki H: Prognostic significnce of expression of CCL5/RANTES receptors in patients with gastric cancer. J Surg Oncol 97: 445-450, 2008.

42. Yang Y, Du L, Yang X, Qu A, Zhang X, Zhou C and Wang C: Aberrant CCR4 expression is involved in tumor invasion of lymph node-negative human gastric cancer. PLoS One 10: e0120059, 2015.

43. Carl-McGrath S, Lendeckel U, Ebert M, Wolter AB, Roessner A and Röcken C: The ectopeptidases CD10, CD13, CD26, and $\mathrm{CD} 143$ are upregulated in gastric cancer. Int $\mathrm{J}$ Oncol 25: 1223-1232, 2004

44. Namikawa $\mathrm{T}$ and Hanazaki K: Mucin phenotype of gastric cancer and clinicopathology of gastric-type differentiated adenocarcinoma. World J Gastroenterol 16: 4634-4639, 2010.

45. Barresi V, Vitarelli E, Grosso M, Tuccari G and Barresi G: Relationship between immunoexpression of mucin peptide cores MUC1 and MUC2 and Lauren's histologic subtypes of gastric carcinomas. Eur J Histochem 50: 301-309, 2006. 
46. Yalcin S, Yildiz Y and Sokmensuer C: Frequency of c-Met, HGF, and HER-2 expression and evaluation of their association with clinicopathologic and prognostic factors in gastric cancer. J Clin Oncol 33 (3 Suppl): S88, 2015.

47. Teng $\mathrm{L}$ and $\mathrm{Lu} \mathrm{J}$ : cMET as a potential therapeutic target in gastric cancer (Review). Int J Mol Med 32: 1247-1254, 2013.

48. Zhu GJ, Xu CW, Fang MY, Zhang YP and Li Y: Detection of Her2/neu expression in gastric cancer: Quantitative PCR versus immunohistochemistry. Exp Ther Med 8: 1501-1507, 2014.

49. Zheng HC, Takahashi H, Murai Y, Zui ZG, Nomoto K, Miwa S, Tsuneyama K and Takano Y: Upregulated EMMPRIN/CD147 might contribute to growth and angiogenesis of gastric carcinoma: A good marker for local invasion and prognosis. Br J Cancer 95: 1371-1378, 2006.

50. Fidler IJ: Critical factors in the biology of human cancer metastasis: Twenty-eighth G.H.A. Clowes memorial award lecture. Cancer Res 50: 6130-6138, 1990.

51. Sharkey FE and Fogh J: Metastasis of human tumors in athymic nude mice. Int J Cancer 24: 733-738, 1979.

52. Zheng MJ, Wang J, Chen YW, Xu L, Xue DD, Fu W, Zhang YF, Du Q, Zhao Y, Ling LJ, et al: A novel mouse model of gastric cancer with human gastric microenvironment. Cancer Lett 325 : 108-115, 2012

53. Kyriazis AP, DiPersio L, Michael GJ, Pesce AJ and Stinnett JD: Growth patterns and metastatic behavior of human tumors growing in athymic mice. Cancer Res 38: 3186-3190, 1978.

54. Chen T, Yang K, Yu J, Meng W, Yuan D, Bi F, Liu F, Liu J, Dai B, Chen $\mathrm{X}$, et al: Identification and expansion of cancer stem cells in tumor tissues and peripheral blood derived from gastric adenocarcinoma patients. Cell Res 22: 248-258, 2012.

55. Wakamatsu Y, Sakamoto N, Oo HZ, Naito Y, Uraoka N, Anami K, Sentani K, Oue N and Yasui W: Expression of cancer stem cel markers ALDH1, CD44 and CD133 in primary tumor and lymph node metastasis of gastric cancer. Pathol Int 62: 112-119, 2012

56. Wu S, Xue W, Huang X, Yu X, Luo M, Huang Y, Liu Y, Bi Z, Qiu X and Bai S: Distinct prognostic values of ALDH1 isoenzymes in breast cancer. Tumor Biol 36: 2421-2426, 2015.

57. You Q, Guo H and Xu D: Distinct prognostic values and potential drug targets of ALDH1 isoenzymes in non-small-cell lung cancer. Drug Des Devel Ther 9: 5087-5097, 2015.
58. Jia J, Parikh H, Xiao W, Hoskins JW, Pflicke H, Liu X, Collins I, Zhou W, Wang Z, Powell J, et al: An integrated transcriptome and epigenome analysis identifies a novel candidate gene for pancreatic cancer. BMC Med Genomics 6: 33, 2013.

59. Kong B, Wu W, Cheng T, Schlitter AM, Qian C, Bruns P, Jian Z, Jäger C, Regel I, Raulefs S, et al: A subset of metastatic pancreatic ductal adenocarcinomas depends quantitatively on oncogenic Kras/Mek/Erk-induced hyperactive mTOR signalling. Gut 65: 647-657, 2016.

60. Saw YT, Yang J, Ng SK, Liu S, Singh S, Singh M, Welch WR, Tsuda H, Fong WP, Thompson D, et al: Characterization of aldehyde dehydrogenase isozymes in ovarian cancer tissues and sphere cultures. BMC Cancer 12: 329, 2012

61. Mao P, Joshi K, Li J, Kim SH, Li P, Santana-Santos L, Luthra S, Chandran UR, Benos PV, Smith L, et al: Mesenchymal glioma stem cells are maintained by activated glycolytic metabolism involving aldehyde dehydrogenase 1A3. Proc Natl Acad Sci USA 110: 8644-8649, 2013.

62. Li K, Guo X, Wang Z, Li X, Bu Y, Bai X, Zheng L and Huang Y: The prognostic roles of ALDH1 isoenzymes in gastric cancer. Onco Targets Ther 9: 3405-3414, 2016.

63. Goedde HW and Agarwal DP: Pharmacogenetics of aldehyde dehydrogenase (ALDH). Pharmacol Ther 45 345-371, 1990.

64. Hidaka A, Sasazuki S, Matsuo K, Ito H, Sawada N, Shimazu T, Yamaji T, Iwasaki M, Inoue M and Tsugane S; JPHC Study Group: Genetic polymorphisms of ADH1B, ADH1C and ALDH2, alcohol consumption, and the risk of gastric cancer: The Japan Public Health Center-based prospective study. Carcinogenesis 36: 223-231, 2015.

This work is licensed under a Creative Commons Attribution-NonCommercial-NoDerivatives 4.0 International (CC BY-NC-ND 4.0) License. 